\title{
Työvoimakoulutukseen hakeutumisen motivaatio ja koulutuksen kokeminen
}

\author{
Työministeriö käynnisti pahimpana lamavuonna 1993 \\ kolme tutkimusta, joissa oli määrä selvittää yksilön, yrityksen ja työ \\ markkinoiden näkökulmasta työvoimapoliittisen koulutuksen vaikuttavuutta. \\ Yksilön näkökulman tutkiminen lankesi Jyväskylän yliopiston Kasvatus \\ tieteiden tutkimuslaitokselle. liris Mikkosen artikkeli perustuu tästä \\ tutkimuksesta juuri valmistuneeseen osaraporttiin. \\ Mitä tuloksista saattoi päätellä? Ainakin sen, että työvoimakoulutukselta \\ odotetaan eväitä nimenomaan ammatilliseen kehittymiseen. Tulokset \\ kertovat myös siitä, että työvoimakoulutuksella on varteenotettavaa \\ merkitystä työttömyyden ei-aineellisten haittojen ehkäisijänä.
}

Työvoimapoliittinen aikuiskoulutus, lyhyemmin työvoimakoulutus, on merkittävä ja laajeneva osa suomalaista ammatillisen aikuiskoulutuksen järjestelmää. Se tarjoaa koulutusta sille väestönosalle, jolla ei elämäntilanteestaan johtuen yleensä ole mahdollisuuksia osallistua aikuisten omaehtoiseen koulutukseen eikä henkilöstökoulutukseen, toisin sanoen se palvelee ennen kaikkea koulutuksen tasa-arvotehtävää kouluttamalla työmarkkinoiden huono-osaisia. Viime aikoina usein esitetty tavoite on ollut luoda koko aikuisväestölle mahdollisuus ammattisuuntautuneeseen peruskoulutukseen ja tarpeelliseen lisäkoulutukseen (mm. koulutussuunnittelun neuvottelukunta 1988 ja opetusministeriön työryhmä 1992). Miten lähellä tai kaukana tämän tavoitteen toteutumisesta nyt ollaan, ja mitä esteitä sen tiellä on, olisi selvittämisen arvoinen asia.

Huolimatta aikuiskoulutuksen lisääntyneestä tarjonnasta eivät erot eri väestöryhmien koulutukseen osallistumisessa ja koulutustasossa ole kuitenkaan mainittavasti tasoittuneet. Kysyä myös sopii, onko koulutusmahdollisuuksien luominen koko aikuisväestölle ylipäänsä realistinen tavoite. Voidaanko odottaa, että nuorisoasteella muita vähemmän koulutusta saaneet ja vähemmän koulutusmotivoituneet aikuisiässä jostain syystä sankoin joukoin osallistuisivat koulutukseen. Vai olisiko aikuisten kohdalla luotettava enemmän Varilan (1994) nimeämän hiljaisen taitotiedon, työtehtäviin kytkeytyvän osaamisen kehittymiseen ilman formaalia koulutusta.

Paitsi aikaisemmat koulutuskokemukset, aikuisen koulutuskiinnostukseen vaikuttaa luonnollisesti myös hänen kulloinenkin elämäntilanteensa ja se, mitä tavoitteita hän koulutukselle ja elämälleen yleensä asettaa. Työttömien osalta on vaarana, että hiljainen taitotieto mykistyy kokonaan työttömyyden jatkuessa, ja siksi työttömien koulutuksella on oma sijansa heidän osaamisensa ylläpidon ja kehittämisen kannalta.

Työvoimakoulutuksen toimeenpanosta ja kehittämisestä vastaavat työvoimaviranomaiset, myös rahoitusvastuu on kokonaan työvoimaviranomaisilla. Koulutusta ostetaan eri järjestäjiltä, esimerkiksi vuonna 1993 hankituista opiskelijatyöpäivistä oli ammatillisten aikuiskoulutuskeskusten osuus $60 \%$, muiden oppilaitosten $24 \%$, korkeakoulujen $7 \%$ ja muiden järjestäjien (mm. työnantajat, yksityiset konsultit) $9 \%$. Koulutuksen aloittaneita oli noin 70000 vuonna 1993, opiskelijatyöpäiviä hankittiin 6,1 miljoonaa ja rahaa koulutuksen hankintaan ja opintososiaalisiin etuihin käytettiin yhteensä hieman yli 2 miljardia markkaa (Työministeriö 1995).

Lain (763/90) mukaan koulutuksen päätavoite on aikuisväestölle koulutusta hankkimalla edistää ja ylläpitää työvoiman kysynnän ja tarjonnan tasapainoa työmarkkinoilla sekä torjua työttömyyttä ja poistaa 
työvoimapulaa. Koulutushankintojen tulee edistää työttömien pysyväisluonteista työllistymistä tai vähentää työttömyyden uhkaa, sekä edistää myöskin tarkoituksenmukaista liikkuvuutta. Koulutukseen osallistuvat ovat pääasiassa työttömiä tai työttömyysuhan alaisia (88 prosenttia vuonna 1993).

Työministeriö on käynnistänyt vuonna 1993 kolme tutkimusta, jotka kolmesta eri näkökulmasta, yksilön, yrityksen ja työmarkkinoiden, pureutuvat työvoimakoulutuksen vaikuttavuuteen. Kiinnostus vaikuttavuuteen liittyy paitsi yleiseen koulutuksen tuloksellisuudesta ja tilivelvollisuudesta käytyyn keskusteluun, myös työhallinnossa heränneeseen tarpeeseen selvittää ja vertailla aktiivisen työvoimapolitiikan toimien vaikuttavuutta yleensä.

Yksi mainituista kolmesta tutkimuksesta on vaikuttavuuteen yksilötason, koulutukseen osallistuvan henkilön näkökulmasta kohdistuva tutkimus, jota tehdään Kasvatustieteiden tutkimuslaitoksella Jyväskylässä. Tämä artikkeli perustuu ko. tutkimuksen ensimmäiseen osaraporttiin '7yövoimapoliittiseen aikuiskoulutukseen hakeutuminen ja koulutuksen kokeminen. Koulutusmotivaatio, koulutukseen kohdistuneet odotukset ja niiden toteutuminen", joka on juuri julkaistu työministeriön Työpoliittinen tutkimus -sarjassa (Mikkonen 1995).

Tutkimuksen laaja empiirinen aineisto muodostuu kaikkiaan neljässä eri vaiheessa postikyselyillä hankittavasta tiedosta, joka koskee noin 5 000:n työvoimakoulutukseen osallistuneen ja samansuuruisen ei-osallistuneen vertailuryhmän (saman ajankohdan työnhakijoita) vaiheita työmarkkinoilla sekä koulutukseen osallistuneiden omia kokemuksia ja subjektiivisia arvioita koulutuksesta ja sen vaikutuksista. Kyseessä on tilastollisesti edustava otos kaikista vuonna 1993 työvoimakoulutuksen aloittaneista. Seuranta ulottuu kaikkiaan kahden vuoden päähän koulutuksen päättymisestä. Ensimmäinen osaraportti perustuu kahden ensimmäisen kyselyn, koulutuksen aloittamis- ja päättämisvaiheeseen ajoitettujen kyselyjen tuottamaan aineistoon.

\section{Koulutustarve ja koulutusintressi}

Koulutustarve on käsitteenä monimerkityksinen eikä sille ole olemassa yhtä yksinkertaista määritelmää. Se nähdään ja koetaan yksilöiden ja organisaatioiden tasolta eri tavalla. Yksilön kokema koulutustarve syntyy hänen elämäntilanteestaan ja suhteessa hänen omalle elämälleen asettamiinsa tavoitteisiin. Koettu koulutustarve ei myöskään aina välttämättä johda koulutukseen hakeutumiseen. Koulutusta suunnittelevat ja toteuttavat organisaatiot tulkitsevat koulutustarvetta omasta, kokonaisuuden näkökulmasta, käyttäen erilaisia menetelmiä ja kuullen eri asiantuntija- ja asianosaistahoja.

Koulutustarve on itse asiassa käsitteenä abstraktio, vaikka se joudutaankin operationalisoimaan yksinkertaisiksi, konkreettisessa muodossa ilmaistaviksi asioiksi. Knowles (1970) erottaa käsitteenä helpommin konkreettisestikin ilmaistavan intressin koulutustarpeesta. Koulutustarve tai intressi on joka tapauksessa olennaisen tärkeä käsite koulutusmotivaation ja sitä kautta myös koulutuksen vaikuttavuuden kannalta.

Työvoimakoulutusta järjestetään työvoimaviranomaisten näkemien, kokemien tai arvioimien koulutustarpeiden pohjalta lähtien laissa asetetuista tavoitteista ja tehtävistä. Koulutustarpeet tulee arvioida ottaen huomioon niin työnhakijoiden, työnantajien kuin muidenkin elinkeinoelämän ja työmarkkinoiden toimivuuden kannalta tärkeiden osapuolten taholta tulevat viestit. Tutkimukseni hakeekin vastausta siihen, miten koulutukseen osallistuneiden henkilöiden yksilöllisesti kokemat koulutustarpeet ja omakohtaiset tavoitteet ovat toteutuneet työvoimakoulutuksessa, toisin sanoen osuvatko organisaation ja yksilöiden kokemat tarpeet yksiin. Tämän kautta tutkimus edustaa siis yksilötason näkökulmaa.

Yksilön koulutusmotivaation voi ajatella syntyvän joko koetusta koulutustarpeesta tai jostain muusta tarpeesta. Andragogisen oppimismallin mukaan "oppimisen lähtökohtana on oppijan sisäinen tarve, jolloin 
oppiminen on sisäisesti motivoitu tapahtuma ja vastuu oppimisesta on oppijalla" (Manninen ym. 1988). jotta tähän päästäisiin, tulisi motivaation olla siis Engeströmin käsittein hyvin lähellä sisällöllistä, tietoista motivaatiota, joka perustuu mielenkiintoon itse asian sisältöä ja käyttömahdollisuuksia kohtaan. Tällöin päädytään usein kriittiseen asenteeseen, koska opiskelija pohtii itse opittavaa asiaa eikä suoriutumista, ja opiskelulla on käyttöarvoa.

Motivaatio voi olla kuitenkin myös vieraantunut, välineellinen, jolloin tavoitellaan enemmänkin ulkoista hyötyä, palkkioita tai pyritään välttämään rangaistuksia tai kielteisiä seuraamuksia. Opiskelulla on vain vaihtoarvoa, tärkeää on osallistuminen tai suoriutuminen sinänsä. Kolmas mahdollisuus on tilannekohtainen opiskelumotivaatio, joka perustuu opiskeluun liittyviin ulkoisiin tekijöihin, esimerkiksi viihdyttävyyteen. Tämä motivaatio on usein lyhytjännitteinen, altis häiriöille ja suuntautuu toisarvoisiin kohteisiin. (Engeström. 1982).

Sekä koulutustarve että -motivaatio ovat koulutuksen vaikuttavuuden kannalta olennaisia osia siinä kokonaisprosessissa, jossa yksilö koulutukseen osallistuessaan on mukana. Tämän prosessin tavoitteeksi voidaan andragogisen mallin mukaan nähdä yksilön kehittyminen aktiivisena toimijana, subjektina. Koulutukselta ei voi odottaa vaikuttavuutta yhteiskunnan eikä yritysten tasolla, ellei tämä yksilötason prosessi toimi. Toimivuuden ensimmäinen edellytys taas on, että prosessi lähtee oikein eli omakohtaisella motivaatiolla liikkeelle.

\section{Työvoimakoulutuksen ryhmittely}

Työvoimakoulutuksen tarjonnan kasvaessa ja koulutuksen järjestäjien kirjon laajentuessa on koulutuksen sisältö samalla ratkaisevasti monipuolistunut. Tässä tutkimuksessa koulutus on ryhmitelty seitsemään tyyppiin kuviossa 1 esitetyn rakenteen mukaisesti lähtien siitä, että erityyppisellä koulutuksella on myös erilaiset tavoitteet ja osallistujilla erilaiset odotukset. Kuusi ensimmäistä tyyppiä (yhteensä noin 4600 henkilöä) muodostavat tutkimuksen pääkohderyhmän, joka on aloittanut koulutuksensa keväällä 1993, ja seitsemäs, tutkintotavoitteisen koulutuksen ryhmä on mukana erillisryhmänä, joka on aloittanut koulutuksensa jo syksyllä 1991.

\section{Kuvio 1. Työvoimakoulutuksen ryhmittely}

\section{AMMATILLINEN \\ TYÖVOIMA \\ KOULUTUS}

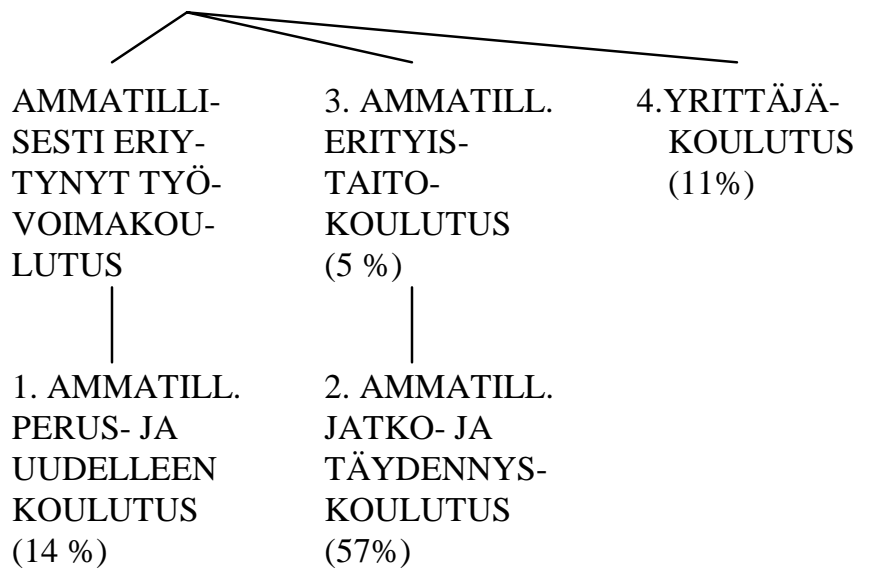

EI-AMMATILLINEN TYÖVOIMAKOULLJTUS

\section{TUTKINTO \\ TAVOITTEINEN \\ KOULUTUS}

Ensimmäinen selkeä kahtiajako on jako ammatilliseen ja ei-ammatilliseen työvoimakoulutukseen. Ammatillinen koulutus voidaan vielä jakaa toisaalta ammatillisesti eriytyneeseen koulutukseen, joka edustaa "perinteistä" työvoimakoulutusta (entinen työllisyyskoulutus) ja on selkeästi tiettyyn ammattiin tai ammattialaan kiinnittyvää (tässä aineistossa $71 \%$ ), sekä ammatilliseen erityistaitokoulutukseen, joka on 
ammatillisesti eriytymätöntä, mutta kuitenkin ammatillista, yleensä kieli- ja atk-koulutusta (5 \%), ja yrittäjäkoulutukseen $(11 \%)$. Ei-ammatillista työvoimakoulutusta taas edustavat ohjaava koulutus (mm. entinen TYKO) (9 \%) sekä ulkomaalaisten koulutus (4 \%). Seitsemäntenä erillisenä ryhmänään on ammatillisten oppilaitosten eri koulutuslinjoilla toteutettava tutkintotavoitteinen koulutus, jota on ostettu yksittäisinä oppilaspaikkoina työvoimahallinnon asiakkaille. Kullakin näistä koulutustyypeistä on selkeästi omat tavoitteensa ja oma kohderyhmänsä, ja siksi myös tuloksia on tarkasteltu yleensä erikseen ammatillisen ja ei-ammatillisen työvoimakoulutuksen osalta, osittain myös koulutustyypeittäin.

Jatkossa esitettävät tulokset ja prosenttiluvut perustuvat siis koulutuksen aloittamis- ja päättämisvaiheisiin ajoitettuihin kyselyihin, joihin vastanneita oli yhteensä noin 3500 (70\%).

\section{Työvoimakoulutukseen hakeutuminen}

Työvoimakoulutukseen hakeudutaan työvoimatoimiston kautta. Koulutusmahdollisuuksista saadaan myös tieto pääasiassa työvoimatoimiston virkailijalta, itsepalvelupäätteeltä tai hallinnon julkaisuista (65 \%), joskin myös sanomalehtien, työmarkkinajärjestöjen julkaisuineen sekä sukulaisten ja tuttavien merkitys tietolähteenä on joissakin ryhmissä näkyvissä.

Työvoimatoimistosta saatu informaatio ei kaikilta osin kuitenkaan ole vastannut asiakkaiden tarpeita. Taloudelliset asiat ovat työvoimakoulutukseen hakeutuville tärkeitä elämäntilanteesta johtuen, ja parhaiten olivatkin kaikissa koulutustyypeissä työvoimatoimistossa selvinneet koulutusaikaiset taloudelliset etuudet (vastaajista 34 \%:n mielestä selvitettiin riittävästi). Tutkintotavoitteinen koulutus on monivuotista ja varmuus taloudellisesta toimeentulosta opiskeluaikana sen vuoksi vielä muita ryhmiä tärkeämpää. Tutkintotavoitteisten ryhmässä olikin $80 \%$ sitä mieltä, että taloudellisia etuuksia oli selvitetty työvoimatoimistossa riittävästi. Toiseksi parhaiten oli vastanneiden mielestä selvitetty koulutuksen tavoitteita ja opetussisältöjä (vastaajista $23 \%$ :n mielestä riittävästi) ja ammatillisen koulutuksen merkitystä yleensä työmarkkinoilla (18 Yo). Sen sijaan vain $11 \%$ oli sitä mieltä, että mahdollisuuksia sijoittua koulutuksen jälkeen työhön oli selvitetty riittävästi. Vastauksissa heijastuvat luonnollisesti myös koulutukseen hakeutuvien omat tarpeet ja odotukset, joiden pohjalta asioiden selvittämisen riittävyyttä arvioidaan. Odotukset ovat aina yksilöllisiä, joten myös ennakkoinformaatio työvoimatoimistossa tulisi kohdentaa yksilöllisten tarpeiden pohjalta, vaikkakin tietyt perusasiat on syytä selvittää kaikille.

Työvoimakoulutukseen hakeutumiseen vaikuttavat monet eri tekijät yhdessä ja eri tavalla eri koulutustyypeissä painottuen. Tutkimuksessa pyydettiin koulutusta aloittamassa olleita arvioimaan 10 eri tekijän merkitystä koulutukseen hakeutumisensa kannalta ja lisäksi nimeämään näistä tekijöistä kaikkein ratkaisevimmin ja toiseksi eniten koulutukseen hakeutumiseen vaikuttanut tekijä. Näitä vastauksia käyttäen haettiin kullekin yksilölle ns. vallitsevaa motivaatiotekijää, eli tekijää, joka vaikkakin usein yhdistyneenä muihin tekijöihin, on kuitenkin arvioitavissa kullakin yksilöllä painoarvoltaan tärkeimmäksi. Alkuperäiset 10 tekijää ryhmiteltiin ensin keskinäisten korrelaatioiden perusteella viideksi motivaatiotekijäryhmäksi, jotka ovat seuraavat:

1. ammattitaidon kehittämiseen liittyvä motivaatio

- haluan hankkia lisäpätevyyttä kehittääkseni ammattitaitoani

- haluan päästä uralla eteenpäin, saada parempaa palkkaa ym.

- haluan kehittää itseäni

2. ammattitaidon hankkimiseen liittyvä motivaatio haluan hankkia itselleni ammatin haluan vaihtaa ammattia koulutus avaa jatkokoulutusmahdollisuuksia

3. taloudelliset tekijät

- koulutus on talouteni kannalta tärkeä vaihtoehto 
- koulutusaikainen taloudellinen tuki

4. toimintahakuinen motivaatio

- haluan jotain toin-fintaa työttömänä olon sijasta

5. ei omakohtaista motivaatiota

- työvoimatoimistosta ehdotettiin tätä koulutusta

\section{Kuvio 2. Motivaatioperusta koulutustyypeittäin}

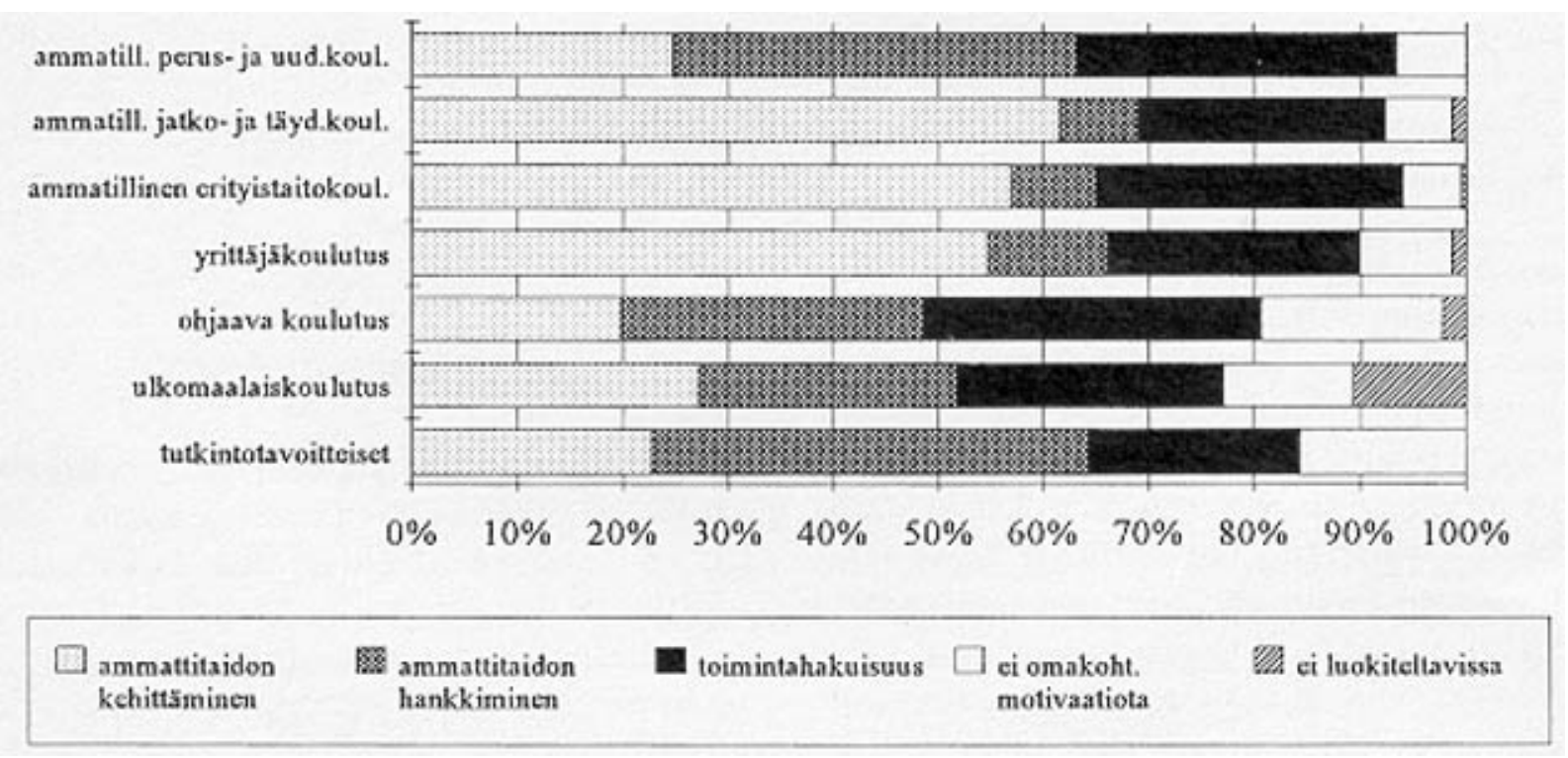

Sen perusteella, mikä näistä motivaatiotekijäryhmistä sai henkilön vastauksissa suurimman painoarvon edellyttäen, että se samalla ylitti tietyn vähimmäistason, luokiteltiin henkilöt kolmeen varsinaiseen motivaatiotyyppiin, ammattitaidon kehittäjiin, ammattitaidon hankkijoihin tai toimintahakuisiin kuuluviksi. Henkilöt, joilla taloudelliset tekijät olivat vallitsevana motivaation lähteenä, luokiteltiin samaan ryhmään tyypin "ei omakohtaista motivaatiota" kanssa, koska taloudellisten tekijöiden korostamisen katsottiin kertovan jostain muusta kuin opiskeluun liittyvästä motivaatiosta. Eri työvoimakoulutustyyppeihin hakeutuvien motivaatioperusta on hieman erilainen, mikä ilmenee kuviosta 2.

Kuten kuviosta voi havaita, hakeudutaan ammatilliseen työvoimakoulutukseen pääosin ammatillisen kehittymisen toivossa, osa kehittääkseen ammattitaitoaan (keskimäärin $56 \%$ ), osa hankkiakseen uuden ammatin tai vaihtaakseen ammattia (11\%o). Myös ohjaavaan ja ulkomaalaiskoulutukseen osallistuvilla löytyy ammatillista motivaatiota (kaikkiaan 50 \% joko ammattitaidon kehittäjiä tai hankkijoita), vaikkakin se vaikuttaa välillisemmin, työvoimakoulutus vasta avaa mahdollisuuksia ammatilliseen kehittymiseen.

Mielenkiintoinen tulos on sen sijaan se, että riippumatta koulutustyypistä työvoimakoulutukseen hakeudutaan usein myös toimintahakuisesti, tavoitteena saada passiivisen ja tapahtumaköyhän työttömyysajan tilalle aktiivista toimintaa, joka jäsentää arkipäivää, tukee itsetuntoa, tuottaa myönteisiä kokemuksia ja antaa uskoa tulevaisuuteen. Toimintahakuisten osuus oli koko pääryhmässä neljännes. Varsinkin pitempään työttömänä olleilla toimintahakuisuus on ymmärrettävä ja myönteinen reaktio, joka osaltaan voi olla estämässä syrjäytymistä. Toimintahakuisuus on sitä yleisempää, mitä pitempään työttömyys oli ennen koulutusta kestänyt, miehillä hieman yleisempää kuin naisilla ja Pohjois-Suomessa asuvilla hieman yleisempää kuin Etelä-Suomessa asuvilla.

Kolme edellä käsiteltyä motivaatiotyyppiä kertovat omakohtaisesti koetusta motivaatiosta, joka ammatillisen motivaation osalta on useimmiten myös tietoinen ja sisällöllinen. Sen sijaan toimintahakuinen 
motivaatiotekijä, vaikka onkin omakohtainen, saattaa kertoa osittain myös välineellisestä motivaatiosta (mielenkiinto osallistumisessa sinänsä). Se voi kuitenkin kuvata myös sisällöllistä motivaatiota, kiinnostusta nimenomaan opiskeluun mielekkäänä, omalta kannalta ja omassa elämäntilanteessa hyödyllisenä toimintana.

Kaikkiaan vain pieni osa $(8 \%)$ aloittaa työvoimakoulutuksen vailla omakohtaista motivaatiota, joko työvoimatoimiston aloitteesta tai taloudellisten tekijöiden houkuttelemana. Ohjaavaan ja ulkomaalaiskoulutukseen samoin kuin tutkintotavoitteiseen koulutukseen osallistutaan useammin kuin muuhun työvoimakoulutukseen ilman omakohtaista motivaatiota $(15 \%)$. Tutkintotavoitteisten osalta tätä selittää taloudellisten tekijöiden muita suurempi painoarvo. Vain noin $2 \%$ jäi tässä aineistossa luokittelematta puutteellisten vastausten vuoksi tai siksi, että mikään tekijä ei saanut merkittävää painoarvoa.

Mitä tuloksista sitten voi päätellä? Ainakin sen, että työvoimakoulutukselta odotetaan merkittävässä määrin nimenomaan eväitä ammatilliseen kehittymiseen. Koulutukseen ei lähdetä työvoimatoimiston houkuttelun vuoksi eikä sattumalta, vaan koulutus valitaan siten, että sen avulla odotetaan voitavan joko hankkia uusi ammattitaito tai kehittää entistä. Toiseksi tulokset kertovat siitä, että työvoimakoulutuksella on merkitystä myös työttömyyden ei-aineellisten haittojen ehkäisijänä. Työttömyyden ahdistavuus ja ehkä pitkäänkin jatkuneesta tuloksettomasta työnhausta syntyvä oma mitättömyyden ja osaamattomuuden tunne ovat tekijöitä, jotka panevat hakemaan muutosta tilanteeseen. Tätä muutosta voi edustaa moni muukin aktiivinen toimintamuoto kuin koulutus, ja siksi tällaisten toimintamuotojen kehittämisessä on niin työttömien omilla järjestöillä kuin monilla muillakin tahoilla valtava toimintakenttä. Tästä näkökulmasta paljon puhutusta koulutuksen käyttämisestä "työttömyyden katkaisukeinona" voikin tulla sisällöllinen, myönteinen asia koulutettavien kannalta eikä vain tilastojen kaunistelua. Työttömyyden passiivisen olotilan katkeamisella ja aktiiviseen toimintaan osallistumisella on yksilölle myönteistä merkitystä. Kolmanneksi tulokset kertovat siitä, että 90 prosenttia hakeutuu nykyään työvoimakoulutukseen omakohtaisella motivaatiolla, ja että ulkopuolisten, lähinnä työvoimaviranomaisten koulutukseen "patistamat" muodostavat vain marginaalisen ryhmän kokonaisuuden kannalta.

\section{Koulutuksen arviointi}

Työvoimakoulutukseen lähteviltä kysyttiin jo koulutuksen aloittamisvaiheessa, mitä he odottivat koulutuksen tilanteeseensa vaikuttavan. Vastauksista heijastui vahva realismi, sillä vain 27 prosenttia pääryhmästä uskoi saavansa työpaikan tai palaavansa entiseen työhönsä koulutuksen jälkeen. Tutkintotavoitteiset, jotka aloittivat koulutuksensa puolitoista vuotta aikaisemmin, olivat huomattavasti optimistisempia, 69 prosenttia uskoi työllistyvänsä. Opiskelemaan uskoi lähtevänsä työvoimakoulutuksen jälkeen joka toinen ei-ammatilliseen työvoimakoulutukseen lähtevä, mutta myös muissa ryhmissä kiinnostus opiskeluun jatkossakin oli huomattavaa. Työttömäksi epäili jäävänsä koulutuksen jälkeen vain 15 prosenttia, erityisen usein työttömyysvaihtoehtoa pitivät todennäköisenä vailla omakohtaista motivaatiota koulutukseen lähteneet.

Koulutuksen päättymisvaiheeseen ajoittuvassa kyselyssä pyydettiin vastaajia sitten arvioimaan käytyä työvoimakoulutusta kolmesta eri näkökulmasta. Ensinnäkin kysyttiin, miten hyvin koulutus oli vastannut odotuksia, toiseksi arvioiko vastaaja ammatillisten valmiuksiensa kehittyneen koulutuksen ansiosta ja kolmanneksi arvioiko hän työllistymismahdollisuuksiensa parantuneen koulutuksen ansiosta. Arviot ovat siis subjektiivisia ja ne on tehty koulutuksen päättymisvaiheessa tai välittömästi koulutuksen päätyttyä. Kokonaisuutena arviot olivat yllättävänkin myönteisiä.

\section{Vastasiko odotuksia?}

Ensinnäkin koulutus oli vastannut odotuksia täysin 46 prosentilla ja osittain 51 prosentilla, eli vain 4 prosenttia ilmoitti, että koulutus ei ollut vastannut lainkaan heidän odotuksiaan. Ei-ammatilliseen työvoimakoulutukseen osallistuneet olivat hieman muita useammin pettyneet täysin odotuksissaan. Vailla omakohtaista motivaatiota koulutukseen lähteneiden odotukset olivat myös täyttyneet muita huonommin. 
Tulos voi tässä ryhmässä kertoa myös koko koulutukseen lähtötilanteen jäsentymättömyydestä, jolloin odotuksia ei ole välttämättä edes tiedostettu. Odotuksissa pettymistä voi kuitenkin selittää myös niiden epärealistisuus, puutteellinen ennakkoinformaatio ja sen herättämät vääränlaiset odotukset tai se, että koulutus ei täyttänyt mitä lupasi. jonkin verran eroja odotusten täyttymisessä oli myös suhteessa siihen, mitä koulutukselta oli odotettu. Ne, jotka olivat odottaneet uusia ihmissuhteita, olivat pettyneet odotuksissaan useammin kuin ne, jotka toivoivat oppivansa uusia tietoja ja taitoja tai toivoivat saavansa uutta intoa elämään. Näyttäisi siis siltä, että työvoimakoulutus palvelee useammin tiedollisten ja taidollisten ja henkisten, mm. itsetuntoon liittyvien tavoitteiden kuin sosiaalisten tavoitteiden saavuttamisessa.

\section{Kehittyivätkö ammatilliset valmiudet?}

Toiseksi vastaajat siis arvioivat, miten heidän ammatilliset valmiutensa kehittyivät koulutuksen ansiosta. Tämä arvio oli astetta varovaisempi kuin edellinen, ja myöskin ero ammatilliseen ja ei-ammatilliseen koulutukseen osallistuneiden välillä oli selvempi. Kun ammatilliseen työvoimakoulutukseen osallistuneista kolmannes arvioi ammatillisten valmiuksiensa kehittyneen huomattavasti, oli vastaava osuus ei-ammatilliseen osallistuneilla vain runsas viidennes. Ero on ymmärrettävä, sillä ammatillisten valmiuksien kehittäminen on välittömästi koulutuksen tavoitteena vain ammatillisessa työvoimakoulutuksessa. Ei-ammatillisessa työvoimakoulutuksessa ammatillisia valmiuksia pyritään kehittämään välillisesti, muiden taitojen ja valmiuksien avulla. Tutkintotavoitteiseen koulutukseen osallistuneet taas arvioivat ammatillisten valmiuksiensa kehittyneen selvästi muita paremmin, kolme neljästä katsoi tapahtuneen huomattavaa kehittymistä.

Motivaatiotyyppien välillä on myös melko selvä ero. Ammattitaidon kehittäjät ja hankkijat arvioivat ammatillisten valmiuksiensa kehittyneen selvästi enemmän kuin toimintahakuiset. Toisin sanoen ne, jotka odottivat ammatillista hyötyä, myös tunnistivat saaneensa sitä useammin kuin ne, jotka eivät odottaneet. Jälkimmäinen ryhmä ei todennäköisesti pitänyt ammatillista kehittymistä yhtä tärkeänä eikä näin ollen ole sitä yhtä helposti havainnut, vaikka sitä olisikin tapahtunut. Koulutuksen pidetessä arvio ammatillisten valmiuksien kehittymisestä näyttää muuttuvan myönteisemmäksi.

\section{Paranivatko työllistymismahdollisuudet?}

Arviot työllistymismahdollisuuksien paranemisesta ovat kolmesta arviosta kaikkein varovaisimpia. Vastaajat ovat todennäköisesti ottaneet myös yleisen työllisyystilanteen huomioon realiteettina, joka työllistymismahdollisuuksiin väistämättä vaikuttaa. Pääryhmästä vain 15 prosenttia arvioi työllistymismahdollisuuksiensa parantuneen koulutuksen ansiosta huomattavasti, kun minkäänlaista paranemista ei nähnyt viidennes. Koulutuksen tavoitteistakin johtuen ammatilliseen työvoimakoulutukseen osallistuneet näkivät koulutuksen parantaneen työllistymismahdollisuuksiaan enemmän kuin ei-ammatilliseen koulutukseen osallistuneet. Eroon vaikuttaa sekin, että työllistymismahdollisuuksiensa paranemista melko välittömästi odottaneet arvioivat tilannetta eri pohjalta kuin ne, jotka eivät pitäneet sitä tässä vaiheessa vielä niin tärkeänä. Ero on siis myös perspektiivissä. Tutkintotavoitteiseen koulutukseen osallistuneet olivat selvästi muita toiveikkaampia, sillä joka kolmas arvioi työllistymismahdollisuuksiensa parantuneen huomattavasti.

Jälleen motivaatiotyypeistä ammattitaidon kehittäjät ja hankkijat arvioivat koulutuksen parantaneen mahdollisuuksiaan enemmän kuin toimintahakuiset ja vailla omakohtaista motivaatiota koulutukseen lähteneet. Samoin mitä pitempää koulutus oli ollut, sitä myönteisemmin sen arvioitiin vaikuttaneen työllistymismahdollisuuksiin.

\section{Johtopäätöksiä}

Työvoimakoulutuksen tarjonta on viime vuosina monipuolistunut niin paljon, että lähes kaikille hakijaryhmille, myös pitemmälle koulutetuille sopivaa koulutusta löytyy, kun sitä vain osataan hakea. 
Oikeanlaisten ratkaisujen tekeminen edellyttää kuitenkin myös monipuolista tietoa koulutuksen tavoitteista ja sisällöstä ja muista koulutukseen hakeutumiseen liittyvistä asioista. Työvoimatoimistot ovat niistä tiedottamisessa avainasemassa, mutta ratkaisu olisi jokaisen koulutukseen hakeutumista harkitsevan tehtävä itse, omakohtaisten intressien ja tavoitteiden pohjalta.

Omakohtainen koulutusmotivaatio on perusedellytys koulutuksen yksilökohtaiselle vaikuttavuudelle, joka vasta voi taata vaikuttavuutta myös yhteiskunnan tasolla. Työvoimakoulutuksen tavoitteena on työmarkkinoiden toimivuuden parantaminen tuottamalla koulutettaville sellaisia ammatillisia tai muita valmiuksia, että heidän työllistymismahdollisuutensa paranevat. Kuitenkin jos koulutuksen merkitystä arvioidaan yksinomaan työllistymiskriteerin perusteella, joudutaan vaikeassa työllisyystilanteessa kyselemään koko järjestelmän mielekkyyden perään, kun enemmistö koulutukseen osallistuneista jää työttömäksi.

Tämän tutkimusaineiston perusteella voi päätellä, että työvoimakoulutuksen aloittavat eivät itsekään kovin suuressa määrin usko välittömään työllistymiseen, vaan koulutukseen lähdetään muilla perusteilla, muunlaisin odotuksin. Suurimmalla osalla tavoitteena on ammatillinen kehittyminen tai ammatin hankkiminen, osalla myöskin pyrkimys saada elämäänsä jäsentävää toimintaa työttömänä olon sijasta. Välittömien arvioiden perusteella työvoimakoulutus on myös vastannut koulutettujen odotuksia kohtalaisen hyvin, joskin toimintahakuisesti koulutukseen hakeutuneet eivät arvioineet hyötyjä yhtä suuriksi kuin ammatillisin tavoittein hakeutuneet.

Ylipäänsä koulutusjärjestelmien arviointi ja oppilaitosten järjestykseen asettaminen pelkän työllistymiskriteerin perusteella on kyseenalaista tilastonikkarointia, jos koulutuksen vaikuttavuutta halutaan arvioida monipuolisesti ja objektiivisesti. Koulutuksen ja työllistymisen yhteys ei ole suoraviivainen: "Hyvä koulutus työllistää nopeasti, huono ei". Arvioinnissa tulisi lähteä koulutukselle sekä järjestelmätasolla että yksilötasolla asetetuista tavoitteista, jotka voivat olla hyvin moniulotteisia, monensuuntaisia ja -tasoisia. Koulutus voi olla hyvin vaikuttavaa kummastakin näkökulmasta, vaikka yksilö ei juuri mittausajankohtana ole työllistynytkään. Toisaalta koulutuksesta on voitu työllistyä nopeasti, vaikka yksilötason tavoitteet koulutuksen suhteen eivät olisi lainkaan toteutuneet. Koulutuksella ja työllistymisellä ei siis ole yksinkertaista syy-seuraus-suhdetta, vaan työllistyminen riippuu monista muista, sekä yksilöön että yleiseen tilanteeseen liittyvistä tekijöistä.

Työvoimakoulutuksen vaikuttavuuteen yksilötasolla kohdistuvassa tutkimuksessa pyritäänkin koulutuksen vaikuttavuuden monipuoliseen arviointiin sekä yksilön omasta näkökulmasta että ulkopuolisin, objektiivisin kriteerein. Kaksi vuotta koulutuksen päättymisen jälkeen kestävä seuranta tuottaa monipuolista tietoa sekä koulutetukseen osallistuneiden että ei-osallistuneiden vaiheista työmarkkinoilla, työ- ja työttömyysjaksoista, opiskelusta ja liikkuvuudesta, mutta myös tietoa koulutettujen subjektiivisista näkemyksistä koskien koulutuksen yhteyksiä näihin vaiheisiin. Tämän artikkelin pohjana ollut ensimmäinen osaraportti on keskittynyt työvoimakoulutukseen hakeutumisen kuvailuun ja selittämiseen, ja vasta tulevissa raporteissa tullaan tämän laajan seuranta-aineiston pohjalta varsinaisesti arvioimaan työvoimakoulutuksen vaikuttavuutta.

\section{LÄHTEET}

Engeström, Y. 1982. Perustietoa opetuksesta. Valtiovarainministeriö: Valtion painatuskeskus.

Knowles, M 1970. The modern practice of adult education: andragogy versus pedagogy. New York: Association Press.

Koulutussuunnittelun neuvottelukunta 1988. Väestön koulutus 2000. Komiteanmietintö 1988.-28 Opetusministeriö. Helsinki: Valtion painatuskeskus. 
Manninen, J. \& Kauppi, A.. \& Kontiainen, S. 1988. Koulutussuunnittelun lähtökohtia. Helsingin yliopisto. Kasvatustieteen laitos. Tutkimuksia 116

Mikkonen, L. 1995. Työvoimapoliittiseen aikuiskoulutukseen hakeutuminen ja koulutuksen kokeminen. Koulutusmotivaatio, koulutukseen kohdistuneet odotukset ja niiden toteutuminen. Työministeriö. Työpoliittinen tutkimus nro 95. Helsinki: Hakapaino Oy.

Opetusministeriö 1992. Sivistys-Suomi 2010. Opetusministeriön työryhmien muistioita 25. Helsinki.

Työministeriö 1995. Työvoimapoliittinen aikuiskoulutus 1993. Työhallinnonjulkaisu 81.

Varila, J. 1994. Hiljainen taitotieto ja henkilöstön kehittäminen. Aikuiskasvatus 14 (3),172-177. 